\title{
The Influence of Virtual Space on Contemporary Identity: The Perspective of Philosophy
}

\author{
LEI CHEN \\ School of Philosophy, Beijing Normal University, 19 Xinwai Street, 100875, Beijing, China \\ Email: leichen@bnu.edu.cn
}

CHENGBING WANG

School of Philosophy, Shanxi University, 92 Wucheng Road, 030006, Taiyuan, China

Email: wangchengbing@sxu.edu.cn

\begin{abstract}
The issue of identity has been a key philosophical topic among philosophers since the beginning of the 21th century. The Virtual space and the Internet have exerted an enormous influence on people's life in the age of information. This article studies the influence of virtual space on identity in the Internet age from the philosophical perspective. The authors think that growth of the influence of computers and network technology on human beings has been a progressive and multi-staged process. Synthesising and analysing the achievements of related research both in China and abroad, it is clear that computers' relationship with human beings has gone through three stages: the first in which the computer was like a tool, the second in which it was like a mirror, and the third in which it is like a gateway or maze, that is, the virtue reality and space. Focusing only on the relations between virtual space and identity 'on the ground', the article proposes that the following two guidelines may aid future inquiry. First, discussing and thinking about the issue of identity from the perspective of relations between virtual space and identity can deepen our understanding of the constituent elements of contemporary identity. Second, the discussion of identity in its relation to virtual space can spur more considerations of the 'self' qua critical concept.
\end{abstract}

Keywords: virtual space, identity, philosophical perspective, who am I, self

\section{INTRODUCTION}

Identity itself is an issue of modernity. In today's philosophical circles the discussion on identity is still very popular. 'The question of who I am, of what or who I take myself to be, can be a vital, even burning question for most of us at some point in our lives' (Carr 2021). With regard to the research approaches, we may see that some philosophers are paying much attention to metaphysics of identity. 'Identity metaphysics finds identity or unity where other theories find difference or diversity. It denies the fundamentality of ontological distinctions 
that other theories treat as fundamental' (Strawson 2021). Some philosophers are considering the differences and relations between the self-identity and personal identity, maintaining that self-identity is rooted in the formal structure of intentional experience, while personal identity 'is rooted in the content of the particular flow of experience, in particular and primarily, in the convictions-cognitive, evaluative, and practical-adopted passively or actively by a self-identical, reflection-capable subject' (Drumond 2021). Some philosophers are now investigating the subjectivity and experiences of people's identity (O'Conaill 2020). Some scholars claim that although considerations of identity play a key role in many areas of moral philosophy, people currently have no satisfactory account of the basis of identity centrality (Mogensen 2021). Some have noticed the influence of consumer culture on identity, 'consumer culture has played an important role in a process of change away from many traditional attitudes. It appears among various traits of contemporary society and has fostered a crisis of identity among some people today' (Wang 2011). The Influence of Virtual Space on Contemporary Identity: From the Perspective of Philosophy is the first English article by Chinese philosophers focusing specifically on the influence of virtue space on contemporary identity. ${ }^{1}$

The virtual space, which is formed by the Internet based on computer technology, has impact on people's identity. Such impact is not only an important practical issue, but also a very worthy academic question. The influence of the Internet on contemporary identity should become a key topic in the discussion of Chinese philosophers, and the main reason therein is that it involves the deconstruction of many inherent concepts (such as entity, space and reality) by the Internet, the impact of modernity upon the traditional concept of communities and methods of communication, and at the same time, shows the contemporary people's new search for meaning and their new construction of the community of meaning of life. The discussion on this issue can enhance our thinking on the philosophical significance of virtual space, on the one hand, and is a try for us to apply a philosophical way of thinking to conduct a case study on the life situations faced by contemporary people, on the other hand.

\section{TOOLS, MIRRORS AND GATEWAY OR MAZE: THREE STAGES OF RELATIONSHIP BETWEEN PEOPLE AND COMPUTER}

The impact of the invention and a widespread use of computers has long-since gone far beyond the sphere of technology itself. Since the mid-20th century, the increasingly extensive use of computers has led to information technology pervading every corner of social production and human life, and providing mankind a completely new sense of community. Researchers in the humanities, social sciences, and natural sciences have accordingly paid incisive and timely attention to the social influence of computers. Just as John Naisbitt pointed out in 1980s that the shift from industrial society to the information society is subtler and more explosive (Naisbitt 1982: 1). In the last two or three decades, the virtual space (also known as network space, or cyberspace) formed by the Internet and internet technology has become

1 We should admit that this article is the extension of our philosophical research on identity which started after we translated the philosophical works on identity 'Sources of the Self: The Making of the Modern Identity' (by Charles Taylor) in 2000. In the past 20 years, we have been doing the research on the influence of globalization on identity and the influence of consumer culture on identity (see Wang 2011). 
a key platform for people's political, economic, cultural, recreational, and emotional life. Virtual space has not only notably improved people's working conditions and working patterns, but is fundamentally influencing their interactions, life styles, modes of consumption, and forms of representation. In our opinion, virtual space properly constitutes a significant part of research on the social influence of computers, and sociological and philosophical approaches to the study of its influence on identity possess a considerable merit.

The growth of the influence of computers and network technology on human beings has been a progressive and multi-staged process. Practitioners of the humanities and social sciences conducting research into the social influence of computers should shift their focus from competitive, external relations between human beings and machines to interactive and integrative ones which are directly connected with contemporary identity.

Synthesising and analysing the achievements of related research both in China and abroad, we can say that computers' relationship with human beings has gone through three stages: the first in which the computer was like a tool, the second in which it was like a mirror, and the third in which it is like a gateway or maze (Turkle 1984).

In the first stage of relations between human beings and computers, beginning with the initial use of electronic computers in the late 1970s, the computer was primarily a useful but expensive tool. In their users' eyes, the major function of computers was to help people with their work, aiding with word processing, mathematical and scientific computation, financial matters, and communication, among other tasks. 'At one level, the computer is a tool. It helps us write, keep track of our accounts, and communicate with others' (Turkle 1995: 9). Effectively, computers were like personal assistants who never asked for salaries, and much work was done to improve the computers' operational conditions. In the early 1980s in China, few ordinary people enjoyed comfortable, air-conditioned housing and working conditions, but many computer rooms were equipped with air-conditioners in the interest of maintaining a constant temperature, were kept tidy and clean, and were run in accordance with certain standards. The primary purpose in doing so was to preserve and maintain these advanced tools so that they could function more smoothly and effectively.

Computers in the second stage were like mirrors, capable of reflecting people's 'self' and his dynamic creativity as an agent. Since this agency mainly refers to the external manifestations of man's abilities to reason and logically think, people naturally viewed computers as 'a second self'. In their minds, because this 'second self' was no more than a representation of the creativity of the human being's rational self, it was possible to view the miracles of computers as the improvement or manifestation of human beings' abilities. In the early 1990s, much was made of competitions between human beings and computers, for example, chess games between the world champion and super computers. People did not feel frustrated or disappointed even when the world chess champions, with enormous computing capacity, were repeatedly defeated by computers; instead, in the eyes of many, the computers' victories were delightful and vivid illustrations of the strength of man's intelligence, the machines' power reflecting the man's endless rationality and creativity.

Once computers are compared to a tool incapable of fatigue and a mirror that reflects the creativity of man's rational self, people inevitably set out to perceive the relations between human beings and computers at a 'one-to-one' level, thereby grasping the social role of the latter. The interaction between one computer and one individual was usually simple, unilateral, and limited; meanwhile, research into the social influence of computers was primarily a macro-level discourse about the enormous influence of computers on people's 
learning, work, and life. Accordingly, humanists and social scientists, computer scientists, and scholars in other related disciplines self-consciously joined forces, exploring the influence of computers and their applications in information technology on human values through the lenses of such disciplines as sociology, psychology, philosophy, and law. People made great efforts to discuss computers' bearing on a myriad of issues, among them: their impact on such concepts as good, evil, and privacy; their abuse, particularly in the commission of computer crimes; their users' professional conduct and humanistic qualities; their impact on intellectual property rights. Of course, we do not deny that as the Internet began to enter into ordinary people's lives, the issue of online living began to draw academic attention. In general, however, the approach to the social influence of computers was objective, and the starting point for research was the binary opposition between human beings and machines. This led people to look at the social role of computers from a proactive and domineering perspective, and discouraged individualised, multi-dimensional, small-scale exploration of computers' social influence.

The image of a gateway or maze is perhaps representative of the third stage of human-computer relations. Since the mid- to late-1990s, rapid changes have occurred in computer technology and its application, and the Internet started to become an inseparable part of people's daily lives. With the real advent of an Internet age, the network space formed by millions of computers and by their users resembles a series of gateways or mazes: they seem to give access to every place imaginable, to follow fair rules, and to be simple, convenient, and practical; yet, they are often full of enticements and traps capable of arousing amazement, exclamation, excitement, depression, anxiety, and fear, often leaving users adrift, having lost their sense of direction or orientation. As internet technology and its application has penetrated into every corner of modern people's lives, the virtual space formed by internet technology is being increasingly extended and enriched: the space is no longer empty, and the actuality within virtual reality is no longer irrelevant to human lives. Virtual communities have ceased being otherworldly, increasingly becoming a requisite part of human beings' real lives and an important place for people to solve sensory and emotional problems. In the faceless communication of virtual space, many seem to have regained the feelings of nostalgia, meaning, and authenticity that had been annihilated or destroyed in real communities by modernization. Virtual space is, essentially, impacting the existing patterns of people's social and emotional lives. 'A rapidly expanding system of networks, collectively known as the Internet, links millions of people in new spaces that are changing the way we think, the nature of our sexuality, the form of our communities, our very identities' (Turkle 1995: 9). And it is in this sense, some scholars discussed the theme of the rise of the net society (see Castells 2010).

Generally speaking, the patterns of human beings' activities within virtual space, featuring laissez-aller, virtuality, and timeliness, have their own particularity. As some scholars have pointed out, such patterns may be embodied as simulation, telepresence, full-body immersion, immersion, interaction, artificiality or networked communication (see Heim 1993). These characteristics of virtual space exercise multiple, unique influences on human beings. One of the major influences is that within a network space, relations between human beings and computers are no longer conducted on the principle of a one-to-one correspondence between human beings and machines, nor on the principle of a directly binary opposition between humans and computers. Instead, the relations between man and machine are more multi-dimensional, dynamic, and mutually integrative, fostering new connections not only 
between man and machine but also among men and machines. Accordingly, investigations into the social influence of computers should also shift from focusing on the simply technical and 'objective' to focusing comprehensively on the integration and interaction of subject and object; from concentrating on macro-level research into computer developers and product users' moral self-rule to concentrating on more micro-level research into the influence of computers on identity. This is because virtual space influences human beings' sense of meaning and experience, and sociologists understand identity as people's source of meaning and experience (Castells 1997: 6).

\section{TWO GUIDELINES FOR FURTHER PHILOSOPHICAL INQUIRY}

It is possible for us to deepen our understanding by examining the social role of computers from the perspective of the influence of virtual space on people's identity, an important problematique of modernity. In other words, such a research orientation is not only inevitable but also proper, insofar as it recognizes that the issue of contemporary identity is one of the key issues concerning modernity.

Identity is not only a hot academic issue, but also a transdisciplinary topic which scholars in the disciplines of sociology, psychology, politics, pedagogy, literature and arts, and philosophy have discussed. This is the reason why identity appears as a different problematique across various disciplines and related academic contexts, though it is mainly represented through such questions as 'Who am I?', 'Where do I come from?', and 'Where am I going?'. In the simplest sense, identity is the process of searching for the meaning (Castells 2010: 26). In general, contemporary people's identity has two dimensions, one longitudinal and the other latitudinal. Its longitudinal aspect is the individual's self-feeling of depth, referring to a subject's constant inward exploration of and speculation about his own meaning and value, which involves self-identity and individual identity. In its latitudinal aspect, identity mainly refers to the sense of social meaning that an agent has formed, which is constantly extended in social activities and intercourse. In this respect, it is variously manifested as social identity, collective identity, and group identity, among others.

Focusing only on the relations between virtual space and identity 'on the ground', we propose that the following two guidelines may aid future inquiry:

First, discussing and thinking about the issue of identity from the perspective of relations between virtual space and identity can deepen our understanding of the constituent elements of contemporary identity.

As an evolving concept with abundant philosophical and sociological connotations, identity is the product of organic and reasonable interactions among many components, and the idealised conception of contemporary identity is a combination of all these critical components (Dunn 1998: 6). As to relations between virtual space and identity, we hold that among the various elements and components of contemporary identity, the continuity of identity appears especially important. Referring to the feeling that one's experience of self makes temporal sense, continuity of identity represents the dynamic coherence of temporal and spatial relations. Individual identity has continuity because an individual's memory can span both time and space (Erikson 1968: 26). Accordingly, within the collective identity (the sense of identity) formed by individual identities, the continuity of identity suggests how one may guarantee the coherence of collective identity in time and space. The issue of identity exists for groups, organizations, nations, and even states. In general, it can be embodied as a feeling of history and historical memory. 
In a traditional society, time and space are connected, and people follow the guidance of tradition in their lives, quietly walking through space and steadily spending time one generation after another. In a modern society, notions of time and space have changed greatly, and thus naturally caused confusion in identity. Virtual space has played a critical part in this. Through its virtuality, redolent of reality, network space has opened up a completely new time-space context. For example, by means of simulation and other methods, one can 'move backwards' or 'move forwards' in an almost realistic way to a given time-space domain. For another example, that one can set and define any new identity one chooses within a network, thereby realising a plurality of identity within that given space, has become normal. To a large degree, all these phenomena are due to the virtual space constituted by computers. In this sense, research into the relations between virtual space and contemporary identity can help us enrich our understanding on the notion that 'the problem of identity is central to the emergence and development of modern society; personal identity is, in effect, a phenomenon of modernity' (Davis 2000: 185).

Second, the discussion of identity in its relation to virtual space can spur more consideration of the 'self' qua critical concept. In a certain sense, the key issue of contemporary identity is nothing more than that of the 'self'. The feeling of meaning, the question of 'who am I', and the concern about sense of place are actually inseparably connected with the concept of self. After the constant edification of the early modern sciences and the Enlightenment, people have become accustomed to the modern concept of self, which underpins such disciplines as sociology, psychology, politics, jurisprudence, and pedagogy. We usually regard the 'self' in the modern sense as unity, continuity. However, in the virtual space, 'the self spins off in all directions' (Turkle 1995: 258), and 'I split my mind' (Turkle 1995: 13). So, the self is no longer understood as something stable and integrating, it instead becomes something unstable and incoherent. 'The essence of this self is not unitary, nor are its parts stable entities' (Turkle 1995: 261).

\section{CONCLUSIONS}

In 'real' life, research into the influence of computers from the perspective of the relations between virtual space and contemporary identity will help us and understand the complexity of practical issues arising from the use of computer technology, the difficulty of solving those issues, and the pertinence of the means of solving them. As has been discussed above, the social influences of virtual space have gradually become more elaborated at the level of daily life. One of virtual space's main manifestations is its impact on contemporary people's identity and on their sense of meaning. The influence of computer networks and virtual space on contemporary people's identity is not unilateral, linear, or spontaneous; instead, it is multiple, complex, and constantly represented. Because computer technology has been maturing, people who live in this networked world have faced unprecedented challenges in understanding the meaning of life. People indulge themselves in virtual space, even losing themselves and their grasp on the meaning of life, and enter into an identity crisis. We therefore suggest that one can address some issues typical in our networked society with an eye towards the influence of virtual space on people's identity.

It is obvious that the Internet has become a requisite part of contemporary daily life. According to the 47th Statistical Report on Internet Development in China issued by the China Internet Network Information Center (CNNIC) (2021), China had 989 million netizens by 
December of 2020. According to the same report, the number of mobile phone netizens amounted to 986 million. ${ }^{2}$ With the constant deepening of modernization in China, the use of the Internet will become increasingly extensive.

Another incontrovertible fact is that young people are the main demographic of Internet users in China, and the major participants in and builders of virtual space. According to the same report mentioned above, $13.5 \%$ of Chinese netizens are 10 to 19 years old and $17.8 \%$ of Chinese netizens are 20 to 29 years old. ${ }^{3}$ While Internet usage has produced positive effects, the use of network space has also led to some family, social, and personal problems. Among these, young people's Internet addiction, and its attendant negative influences, is especially significant. Individuals, families, schools, and society have paid a significant price for this, including financial, material, and labour costs, and many young people have lost their academic careers or jobs because of their indulgence; some even commit crimes. In our opinion, reduced self-control and addiction in Internet use have complicated causes, and accordingly the measures deployed to treat Internet addiction should be diversified and individualised as well. Virtual space has exercised an enormous impact on people's identity, spoiling their inherent feeling of identity and their sense of meaning; such problems are somewhat inevitable when one paradigm of identity has been banished or diminished, and a new one grows. If we simply or crudely view problematic phenomena as morbid addictions, we will misconceive their true cause and fail to undertake the proper remedies. Meanwhile, now that there exist intricate relations between network space and human beings' identity, one cannot expect to fundamentally solve problems solely through simple edification, examples, sport exercises, or external stimulation (for instance, brain surgery, electroshock therapy, and other extreme methods introduced by the media). Therefore, we believe that the approach to research suggested in this article may prove helpful.

Received 29 July 2021

Accepted 13 December 2021

\section{References}

1. Carr, D. 2021. 'Personal Identity Is Social Identity', Phenomenology and the Cognitive Sciences 20(2): 342.

2. Castells, M. 1997. The Power of Identity. Blackwell Publishers Inc.

3. Castells, M. 2010. The Rise of the Network Society. Wiley-Blackwell.

4. Davis, J. E. 2000. Identity and Social Change. New Jersey: Transactions Publishers.

5. Drumond, J. J. 2021. 'Self-identity and Persona Identity', Phenomenology and the Cognitive Sciences 20(2): 245.

6. Dunn, R. G. 1998. Identity Crises. University of Minnesota Press.

7. Erikson, E. H. 1968. Identity, Youth and Crisis. W. W. Norton \& Company.

8. Heim, M. 1993. The Metaphysics of Virtual Reality. New York: Oxford University Press.

9. Mogensen, A. L. 2021. 'Is Identity Illusory?', European Journal of Philosophy 29(1): 55-73.

10. Naisbitt, J. 1982. Megatrends: Ten New Directions Transforming Our Lives. New York: Warner Books.

11. O'Conaill, D. 2020. 'The Identity of Experiences and the Identity of the Subject', Philosophical Studies 177(4): 987-1005.

12. Strawson, G. 2021. 'Identity Metaphysics', The Monist 104(1): 69.

13. Turkle, S. 1984. The Second Self: Computers and the Human Spirit. Simon \& Schuster.

14. Turkle, S. 1995. Life on the Screen: Identity in the Age of the Internet. Simon \& Schuster.

15. Wang, C. B. 2011. 'Consumer Culture and the Crisis of Identity', Journal of Value Inquiry 45(3): 293-298.

$\begin{array}{ll}2 & \text { http://www.gov.cn/xinwen/2021-02/03/5584518/filesbd16adb558714132a829f43915bc1c9e.pdf } \\ 3 & \text { http://www.gov.cn/xinwen/2021-02/03/5584518/filesbd16adb558714132a829f43915bclc9e.pdf }\end{array}$ 
LEI CHEN, CHENGBING WANG

\title{
Virtualios erdvės įtaka šiuolaikinei savasčiai: filosofinė perspektyva
}

\begin{abstract}
Santrauka
Savasties problema yra esmine filosofinè tema nuo XXI a. pradžios. Virtuali erdvè ir internetas padarè milžinišką įtaką žmonių gyvenimui informacijos amžiuje. Šis straipsnis nagrinėja virtualios erdvès įtaką savasčiai interneto amžiuje iš filosofinès perspektyvos. Autoriai mano, kad interneto ir ryšių technologijų ịtakos žmonėms didejjimas buvo pažangus kelių pakopų procesas. Sintezuojant ir analizuojant tyrimus Kinijoje ir kitose šalyse tampa aišku, kad kompiuterio ryšys su žmonėmis perèjo tris etapus: pirma, kai kompiuteris buvo įrankis; antra, kai kompiuteris buvo kaip veidrodis; trečia, kai kompiuteris yra kaip vartai ar labirintas, t. y. virtuali realybè ir erdvè. Orientuojantis ị ryšius tarp virtualios realybės ir „žemiškosios“ savasties, straipsnyje teigiama, kad šios dvi gairés gali turèti ịtakos tyrimams ateityje: pirma, savasties temos aptarimas ir apmąstymas iš virtualios realybès ir savasties ryšiu perspektyvos gali pagilinti mūsų supratimą apie šiuolaikinès savasties sudarančiuosius sandus; antra, savasties ryšio su virtualia erdve aptarimas gali paskatinti daugiau „pats“ kaip kritinės sąvokos apsvarstymų.
\end{abstract}

Raktažodžiai: virtuali erdvè, savastis, filosofinè perspektyva 